\title{
Investigation of hydrazine electrooxidation performance of carbon nanotube supported Pd monometallic direct hydrazine fuel cell anode catalysts
}

\author{
Omer Faruk Er, ${ }^{1}$ Ali Cavak, ${ }^{1}$ Adnan Aldemir, ${ }^{1}$ Hilal Kivrak ${ }^{1, *}$ \\ ${ }^{1}$ Van Yuzuncu Yil University, Faculty of Engineering, Department of Chemical Engineering, Van 65000, Turkey, \\ hilalkivrak@yyu.edu.tr, hilalkivrak@gmail.com, ORCID: 0000-0001-8001-7854
}

\section{A B S T R A C T}

In this study, carbon nanotube (CNT) supported Pd/CNT catalysts at varying Pd molar ratios (Pd involving among 0.1-20 wt \%) are prepared via $\mathrm{NaBH}_{4}$ reduction method. The surface of catalysts prepared for hydrazine electrooxidation are successfully characterized via $\mathrm{N}_{2}$ adsorption-desorption measurements, X-ray diffractometer (XRD), X-ray photoelectron spectroscopy (XPS), and transmission electron microscope (TEM). Electrochemical measurements are performed using cyclic voltammetry (CV) and electrochemical impedance spectroscopy (EIS) techniques. According to the characterization results, for $5 \% \mathrm{Pd} / \mathrm{CNT}$ catalyst, the average particle size and the surface area are determined as $5.17 \mathrm{~nm}$ and $773.10 \mathrm{~m}^{2}$ $\mathrm{g}^{-1}$, respectively. Among Pd containing (0.1-20 wt \%) CNT supported catalysts, 5\%Pd/CNT catalyst exhibits the best current density as $6.81 \mathrm{~mA} \mathrm{~cm}^{-2}$ (1122.63 $\left.\mathrm{mA} \mathrm{mg}^{-1} \mathrm{Pd}\right)$. Furthermore, $5 \% \mathrm{Pd} / \mathrm{CNT}$ catalyst shows the best charge transfer resistance (Rct) compared to $\mathrm{Pd} / \mathrm{CNT}$ catalysts. Pd/CNT catalysts are promising anode catalysts for direct hydrazine fuel cells.

\section{ARTICLE INFO}

\section{Research article}

Received: 28.09.2020

Accepted: 17.12 .2020

Keywords:

$P d$,

CNT,

hydrazine, electrooxidation, direct hydrazine fuel cell, anode

*Corresponding author

\section{Introduction}

The demand for energy, in which the vast majority of this demand is provided from fossil fuel is constantly increasing in the industrialized world $[1,2]$. The use of fossil fuels that caused global warming and environmental pollution is constituted negative consequences for both nature and human life [3]. Fuel cell technologies could be employed to supply energy to cover the energy demand instead of fossil fuels [4].

Recently, the most commonly used fuels in fuel cell technology are hydrazine, formic acid [5], ethanol [6], methanol [7], glucose [8], and ethylene glycol [9] etc. Hydrazine is a preferable fuel due to its superior properties such as high energy density, low cost, zero $\mathrm{CO}_{2}$ emission, convenient storage, and transportation ease [10, 11]. In addition, another feature of hydrazine is that its source $\left(\mathrm{H}_{2}\right.$ and $\mathrm{N}_{2}$ ) is unlimited in nature. Hydrazine is not explosive and it has low toxicity in dilute aqueous solutions [11]. In direct hydrazine fuel cells (DHFC), catalyst poisoning products such as $\mathrm{CO}$ do not release, so the overvoltage of catalyst poisoning is low in DHFC [12]. Anode, cathode, and overall reaction of hydrazine electrooxidation are given as follows [13, 14]:
Anodic reaction:

$$
\mathrm{N}_{2} \mathrm{H}_{4}+4 \mathrm{OH}^{-} \longrightarrow \mathrm{N}_{2}+4 \mathrm{H}_{2} \mathrm{O}+4 \mathrm{e}^{-}
$$

Cathodic reaction:

$$
\mathrm{O}_{2}+2 \mathrm{H}_{2} \mathrm{O}+4 \mathrm{e}^{-} \longrightarrow 4 \mathrm{OH}^{-}
$$

Overall reaction:

$$
\mathrm{N}_{2} \mathrm{H}_{4}+\mathrm{O}_{2} \longrightarrow \mathrm{N}_{2}+2 \mathrm{H}_{2} \mathrm{O}
$$

As a result of reactions (1-3) occurring in the oxidation of hydrazine, only water and nitrogen are formed as products, and these products are released into the environment [15].

There are needs for low cost and more efficient catalysts with higher catalytic activity in hydrazine fuel cells. For this purpose, $\mathrm{PtCu} / \mathrm{C}$ [16], $\mathrm{P}-\mathrm{Cu}_{2} \mathrm{Ni} / \mathrm{C}$ [17], NiCoP/C [18], SeNCM [19], $\mathrm{Ni}_{3} \mathrm{~S}_{2} @ \mathrm{Ni}$ foam [20], $\mathrm{Mn}_{2} \mathrm{O}_{3}-\mathrm{Fe} 2 \mathrm{O}_{3} / \mathrm{CFs}$ [21], $\mathrm{Ni}-\mathrm{Pt} / \mathrm{C}$ [22], nano-CuO/MGCE [23], $\mathrm{Ni}_{3} \mathrm{~N}$ nanoparticles [24], $\mathrm{Co}_{\text {fiber }} / \mathrm{Cu}$ [25], $\mathrm{Ni}_{2} \mathrm{P} @ \mathrm{Ni}_{10} \mathrm{Mo} / \mathrm{Ni}-\mathrm{Mo}-\mathrm{O} / \mathrm{NF}$ [26], and $\mathrm{Ni}$ foam@Ag-Ni [27] catalysts were studied in DHFC for catalysts with low costs and higher catalytic activity. In addition, Yang et al. stated that the Ag/CNT catalyst prepared by modification Ag nanoparticles on CNT with benzyl 
mercaptan showed high catalytic activity the hydrazine electrooxidation reaction [28]. In another study, Gao et al. remarked that $\mathrm{Cu}$ nanotube-graphene paper (Cu-GP) electrode developed by the facile electrodeposition method had high electrocatalytic activity and durability for DHFC in alkaline medium [29]. Furthermore, Asset et al. reported that NiMo/C catalyst prepared via wet impregnation process method, exhibited better catalytic activity compared to $\mathrm{Ni} / \mathrm{C}$ catalyst
[30]. Liu et al. reported that the ternary CuNiCo LDH nanosheet array catalyst prepared via sulfurization-induced edge amorphization exhibited good catalytic activity and power durability[31]. The catalysts and maximum peak values compiled from the literature studies for hydrazine electrooxidation were given in Table 1.

Table 1: Catalysts and maximum peak values for hydrazine electrooxidation compiled from literature.

\begin{tabular}{lccrr}
\hline \multicolumn{1}{c}{ Catalyst } & Preparation & $\begin{array}{c}\text { Maximum Peak } \\
\text { mA } \mathbf{~ m}^{-2}\end{array}$ & Reference \\
\hline Pd black & --- & 4.12 & {$[32]$} \\
\hline Pd NCs & --- & 4.87 & {$[32]$} & {$[32]$} \\
\hline AuPd NCs & simple one-pot successive co-reduction & 5.28 & {$[32]$} \\
\hline AuPd DANCs & simple one-pot successive co-reduction & 9.57 & {$[33]$} \\
\hline Co@NM & electrochemical deposition & 8.13 & {$[34]$} \\
\hline VGNH-45 & scalable plasma-enhanced chemical vapor & 13 & {$[35]$} \\
\hline Bulk Au electrode & deposition & 0.9 & {$[35]$} \\
\hline NPGL30 & --- & 10.5 & {$[36]$} \\
\hline MnO/N-C & etching 12-carat white gold leaves & 6.3 & In this study \\
\hline Pd/CNT & --- & 6.81 & \\
\hline
\end{tabular}

In this study, Pd/CNT catalysts were prepared at varying Pd weight loadings via $\mathrm{NaBH}_{4}$ reduction method. The electrochemical performances of prepared catalysts were investigated via $\mathrm{CV}$ and EIS. These catalysts were characterized with advance surface characterization methods as XRD, XPS, and TEM to describe the surface chemical and physical properties. The particle size and the crystal structure of synthesized catalysts were determined via XRD and TEM.

\section{Experimental measurement}

\subsection{Materials and Equipment}

Potassium tetrachloropalladate (II) ( $\left.\mathrm{K}_{2} \mathrm{PdCI}_{4}, 99.99 \%\right)$, Hydrazine $\left(\mathrm{NH}_{2} \mathrm{NH}_{2}, 98 \%\right)$ sodium borohydride $\left(\mathrm{NaBH}_{4}\right.$, 99\%), multi-walled carbon nanotube (MWCNT, 98\%), KOH were purchased from Sigma-Aldrich and used as received. Nafion 117 solution (5\%) was supplied from Sigma-Aldrich. $\mathrm{Ag} / \mathrm{AgCl}$ reference electrode and Pt wire electrodes used in potentiostat were purchased from $\mathrm{CH}$ Instruments. Deionized water was distilled via water purification system (Milli-Q Water Purification System). All glass wares were washed with acetone and a wealth of rinsed with distilled water.

\subsection{Preparation of catalysts and working electrodes}

\subsubsection{Synthesis of $P d / C N T$ catalysts}

$\mathrm{Pd} / \mathrm{CNT}$ catalysts were prepared by $\mathrm{NaBH}_{4}$ reduction method. Pd metal precursor (Potassium tetrachloropalladate) was completely dissolved in pure water and then CNT was added. These mixtures were stirred in ultrasonic bath for two hours.
$\mathrm{NaBH}_{4}$ was added to this mixture to reduce the salts in the medium. After the addition of $\mathrm{NaBH}_{4}$, these mixtures were stirred in the ultrasonic bath for one hour and filtered. These catalysts were completely dried at $85{ }^{\circ} \mathrm{C}$ for 12 hours.

\subsubsection{Preparation of working electrodes}

The working electrode (glassy carbon electrode) was firstly polished by alumina. $3 \mathrm{mg}$ of catalyst was distributed homogenously in $1 \mathrm{~mL}$ of $5 \%$ Nafion solution. Consequencely, a catalyst ink was obtained. Finally, $3 \mu \mathrm{l}$ of catalyst ink was dropped on a working electrode and the electrode was dried at room temperature to remove the solvent.

\subsection{Metal Characterization Techniques}

$\mathrm{Pd} / \mathrm{CNT}$ catalysts were characterized via $\mathrm{N}_{2}$ adsorptiondesorption, XRD, XPS, and TEM. Surface areas were measured through Micromeritics 3Flex equipment. The Pd diffractions on the surface that $5 \% \mathrm{Pd} / \mathrm{CNT}$ of the best ratio of these catalysts were determined using XRD. Particle size and surface metal distribution were found via TEM.

\subsection{Electrochemical Measurements}

All electrochemical measurements of Pd/CNT catalysts were determined by $\mathrm{CV}$ and EIS in $1 \mathrm{M} \mathrm{KOH}+0.5 \mathrm{M} \mathrm{N}_{2} \mathrm{H}_{4}$ solution. These measurements were obtained using the threeelectrode system in potentiostat CH660E. The electrooxidation activities of these catalysts were performed by $\mathrm{CV}$ at the potential gap of $-1.2 \mathrm{~V}$ to $0.8 \mathrm{~V}$ at $50 \mathrm{mv} \mathrm{s}^{-1}$ scan rate. The electrochemical impedances of these catalysts were 
obtained with EIS at $316 \mathrm{kHz}$ and $0.046 \mathrm{~Hz}$ to $5 \mathrm{mV}$ amplitude.

\section{Results and discussion}

\subsection{Physical characterization}

5\% Pd/CNT catalyst was characterized by BET, XRD, XPS, and TEM. Fig. 1 shows the $\mathrm{N}_{2}$ adsorption-desorption isotherm and XRD pattern of monometallic 5\% Pd/CNT catalyst prepared via $\mathrm{NaBH}_{4}$ reduction method. 5\% Pd/CNT catalyst exhibited V-type adsorption-desorption shape with H1 type hysteresis loop (Fig. 1a) [5, 37]. Adsorption-desorption hysteresis loop is close to mesoporous pore structure. The average particle size, pore size, and pore volume of $5 \%$ $\mathrm{Pd} / \mathrm{CNT}$ catalyst were found at $7.76 \mathrm{~nm}, 11.35 \mathrm{~nm}, 2.08 \mathrm{~cm}^{3}$ $\mathrm{g}^{-1}$, respectively. Furthermore, BET surface area of $5 \%$ $\mathrm{Pd} / \mathrm{CNT}$ was calculated as $773.10 \mathrm{~m}^{2} \mathrm{~g}^{-1}$.

The XRD pattern of monometallic Pd/CNT catalyst is given in Figure 1b. It is found that the $C\left(\begin{array}{lll}0 & 0 & 2\end{array}\right)$ plane, which related to reflection of hexagonal carbon structure, diffraction peak located towards 25.6 [38]. The (1 111$)$, (2 $\left.\begin{array}{lll}2 & 0 & 0\end{array}\right),\left(\begin{array}{lll}2 & 2 & 0\end{array}\right)$, and (3 1 1) planes, which shows face center cubic (fcc), belonging to $\mathrm{Pd}$ the diffraction peaks are subtended of $2 \theta$ values at $39.2^{0}$, $45.4^{0}, 66.6^{0}$, and $79.7^{0}$, respectively [39]. In addition, Pd (1 1 0 ) diffraction peak was seen at $42.8^{0}$ [40]. The crystal size for $5 \% \mathrm{Pd} / \mathrm{CNT}$ catalyst was calculated as $6.94 \mathrm{~nm}$ with the Scherrer's equation.

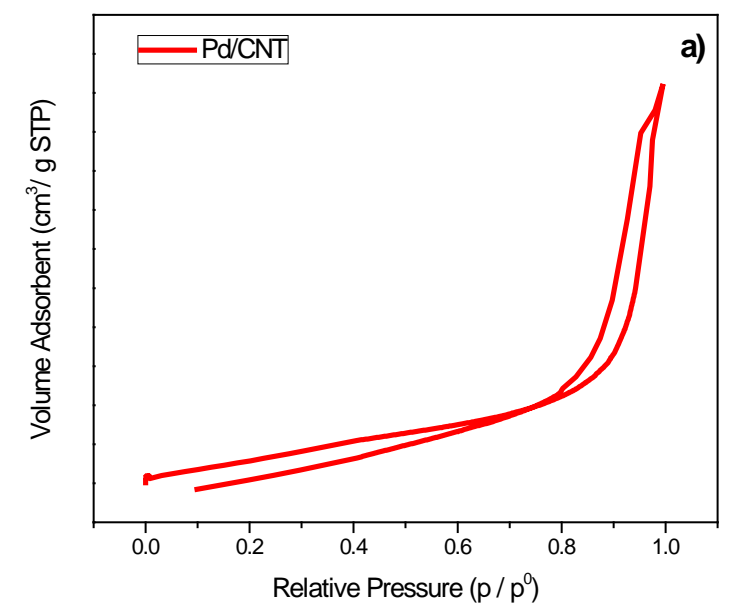

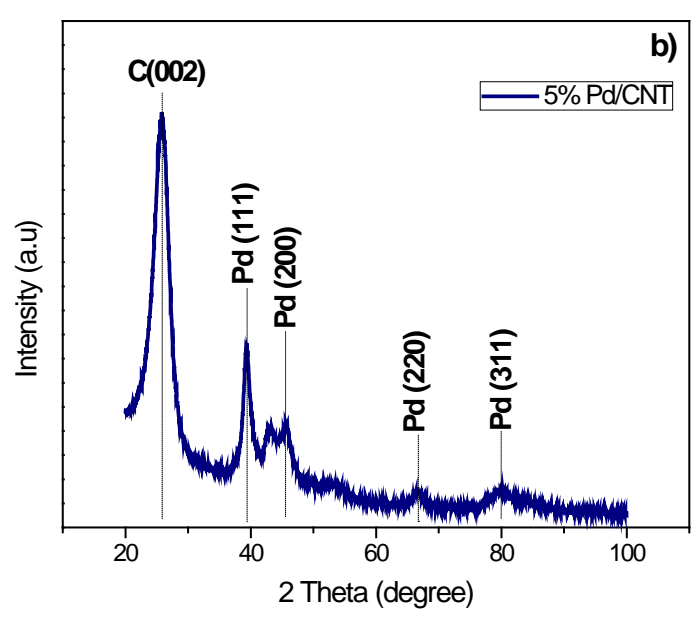

Figure 1. a) $N_{2}$ adsorption-desorption isotherm and b) XRD pattern of the monometallic 5\% Pd/CNT catalyst.

Atomic differences on the CNT surface could be easily determined via XPS analysis [41]. The oxidation state of the Pd on CNT surface was determined by XPS analysis. Here, according to $\mathrm{C} 1 \mathrm{~s}$, which found at 284.4, was determined the binding energy of Pd (Fig. 2b). XPS spectra of Pd 3d, C 1s, O $1 \mathrm{~s}$, and general survey were given in Fig. 2 and the oxidation state of $\mathrm{Pd} 3 \mathrm{~d}$ is presented in Table 2 for $5 \% \mathrm{Pd} / \mathrm{CNT}$ catalyst. The resolution of $\mathrm{Pd} 3 \mathrm{~d}$ spectra was found for $\mathrm{Pd}^{0}\left(3 \mathrm{~d}_{5 / 2} 335.6\right.$ $\left.\mathrm{eV} ; 3 \mathrm{~d}_{3 / 2} 341.9 \mathrm{eV}\right)$ and $\mathrm{Pd}^{2}\left(\mathrm{PdO}_{2} 339.0 \mathrm{eV}\right.$ ) (Fig. 2a and Table 2). In addition, the undefined spectrum was seen at $351.2 \mathrm{eV}$ that could be impurity remaining from the synthesis method (Table 2). The elemental state of $\mathrm{Pd}^{0}$ on CNT surface was determined at relative density as 49.4 (Table 2). TEM was used to determine the particle size and morphological structure of 5\% Pd/CNT catalyst. TEM images and particle size histogram of $5 \% \mathrm{Pd} / \mathrm{CNT}$ catalyst is given in Fig.3. It is clearly seen that $\mathrm{Pd}$ nanoparticles were bonded with the exterior surface of CNT. Furthermore, from Fig. 3(b and c), one could note that Pd nanoparticles aggregated. In addition, Pd nanoparticles distributed homogeneously on the surface of CNT. It was found that the average particle size of $5 \%$ $\mathrm{Pd} / \mathrm{CNT}$ catalyst as $5.17 \mathrm{~nm}$ (Fig. 3(f)). 

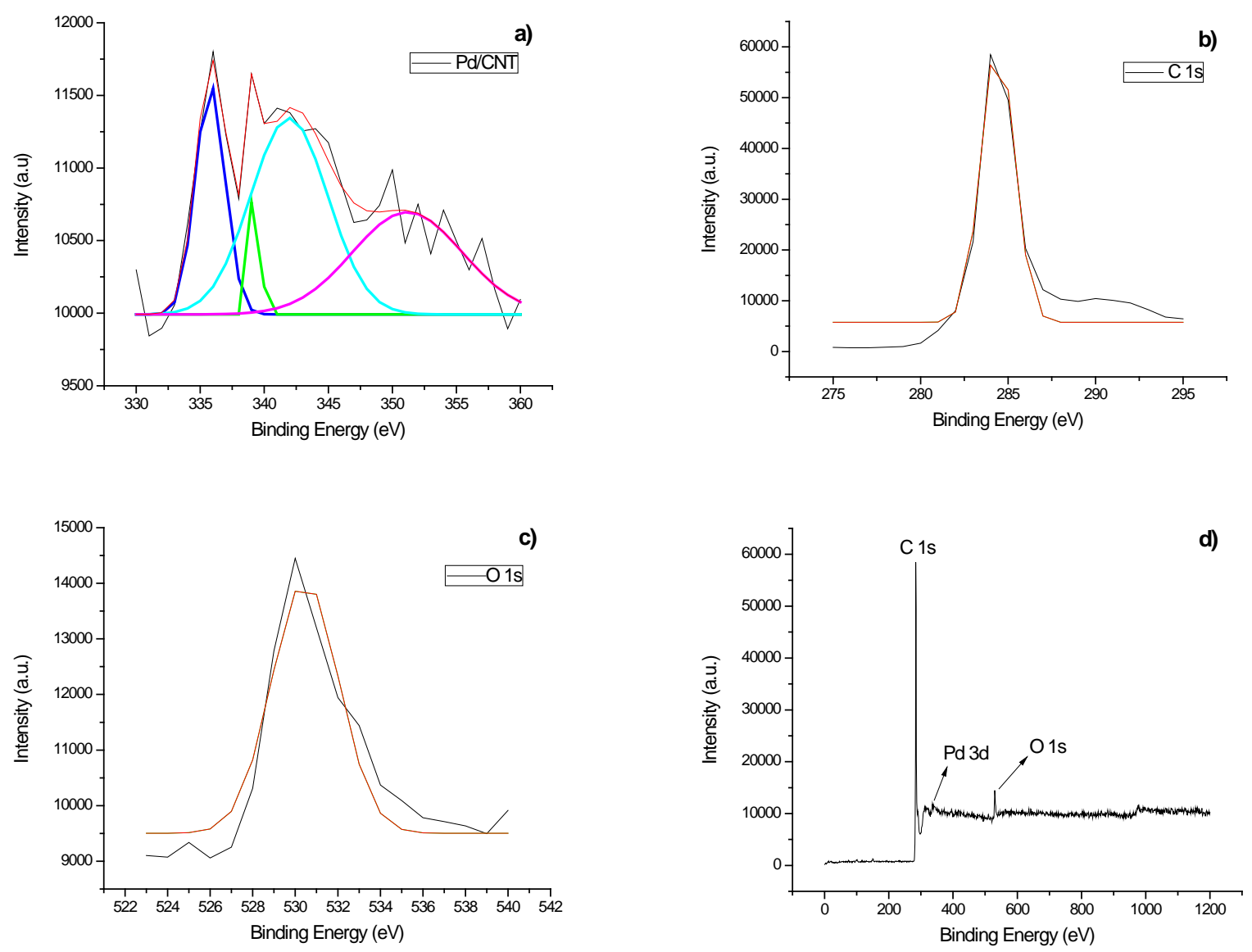

Figure 2. XPS spectra of a) Pd 3d, b) C 1s, c) O 1s, and d) general survey of Pd/CNT catalyst.

Table 2. Pd 3d binding energy of Pd/CNT electro-catalysts.

\begin{tabular}{llllll}
\hline Catalyst & Species & $\begin{array}{l}\text { Binding Energy } \\
(\mathbf{e V})\end{array}$ & $\begin{array}{l}\text { Possible Chemical } \\
\text { State }\end{array}$ & $\begin{array}{l}\text { Relative } \\
\text { Intensity (\%) }\end{array}$ & Reference \\
\hline & & 335.6 & $\mathrm{Pd} \mathrm{3d}_{5 / 2}\left(\mathrm{Pd}^{0}\right)$ & 24.5 & {$[42]$} \\
\cline { 3 - 5 } & \multirow{3}{*}{$\mathrm{Pd} / \mathrm{CNT}$} & $\mathrm{Pd} 3 \mathrm{~d}$ & $\mathrm{PdO}_{2}$ & 24.7 & {$[43]$} \\
\cline { 3 - 5 } & & $\mathrm{Pd} \mathrm{3d}_{3 / 2}\left(\mathrm{Pd}^{0}\right)$ & 24.9 & {$[42]$} \\
\hline
\end{tabular}



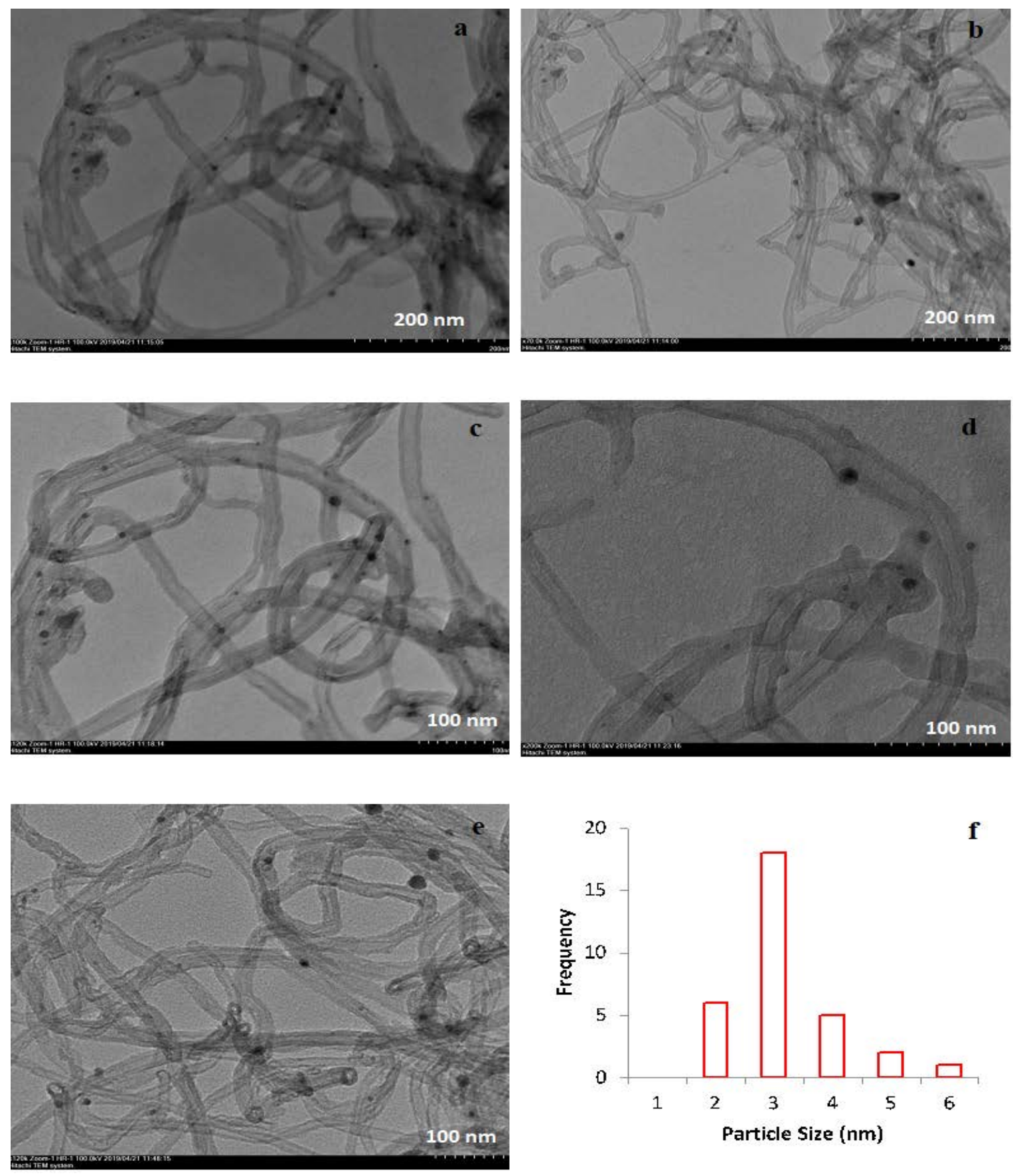

Figure 3. TEM images ( $a, b, c, d$, and e) and particle size ( $f$ ) of $5 \% \mathrm{Pd} / \mathrm{CNT}$.

\subsection{Electrochemical assessment}

$\mathrm{CV}$ and EIS measurements were taken in $1 \mathrm{M} \mathrm{KOH}+0.5 \mathrm{M}$ $\mathrm{N}_{2} \mathrm{H}_{4}$ solution to determine hydrazine oxidation activities of $\mathrm{Pd} / \mathrm{CNT}$ supported catalysts prepared at (0.1-20 wt \%) Pt loadings via $\mathrm{NaBH}_{4}$ reduction method. Initially, CV measurements of prepared catalysts were taken in $1 \mathrm{M} \mathrm{KOH}$ solution and in $1 \mathrm{M} \mathrm{KOH}+0.5 \mathrm{M} \mathrm{N}_{2} \mathrm{H}_{4}$ solution at $-1.0 \mathrm{~V}$ to $0.4 \mathrm{~V}$ potentials a scan rate of $50 \mathrm{mV} \mathrm{s}^{-1}$, respectively. These results were presented in Fig. 4 and Table 3. The hydroxide
$\left(\mathrm{OH}^{-}\right)$adsorption-desorption peak was observed at among -0.4 $\mathrm{V}$ and $0.2 \mathrm{~V}$ for $0.1 \% \mathrm{Pd} / \mathrm{CNT}$ catalyst, but this peak was observed at $-0.3 \mathrm{~V}$ and $0.2 \mathrm{~V}$ for $5 \% \mathrm{Pd} / \mathrm{CNT}$ catalyst (Fig. 4(a)). This could be explained by the fact that Pd nanoparticles are very well dispersed on the CNT surface, and thus lead to more $\mathrm{OH}^{-}$adsorption. As seen, $\mathrm{OH}^{-}$electrooxidation peaks for all prepared catalysts were seen. After reducing the surface oxidation of the catalyst, more Pd active sites were provided for adsorption and oxidizing the hydrazine. 5\% Pd/CNT 
catalyst among the prepared catalysts showed the highest performance as $6.81 \mathrm{~mA} \mathrm{~cm}{ }^{-2}\left(1122.63 \mathrm{~mA} \mathrm{mg}^{-1} \mathrm{Pd}\right)$ for hydrazine electrooxidation (Fig. 4(b) and Table 3). In addition, the forward currents $\left(\mathrm{I}_{\mathrm{f}}\right)$ and reverse currents $\left(\mathrm{I}_{\mathrm{r}}\right)$ of these catalysts were studied. After evaluation of these results, we concluded that $5 \% \mathrm{Pd} / \mathrm{CNT}$ catalyst had the best activity for hydrazine electrooxidation (Table 3).
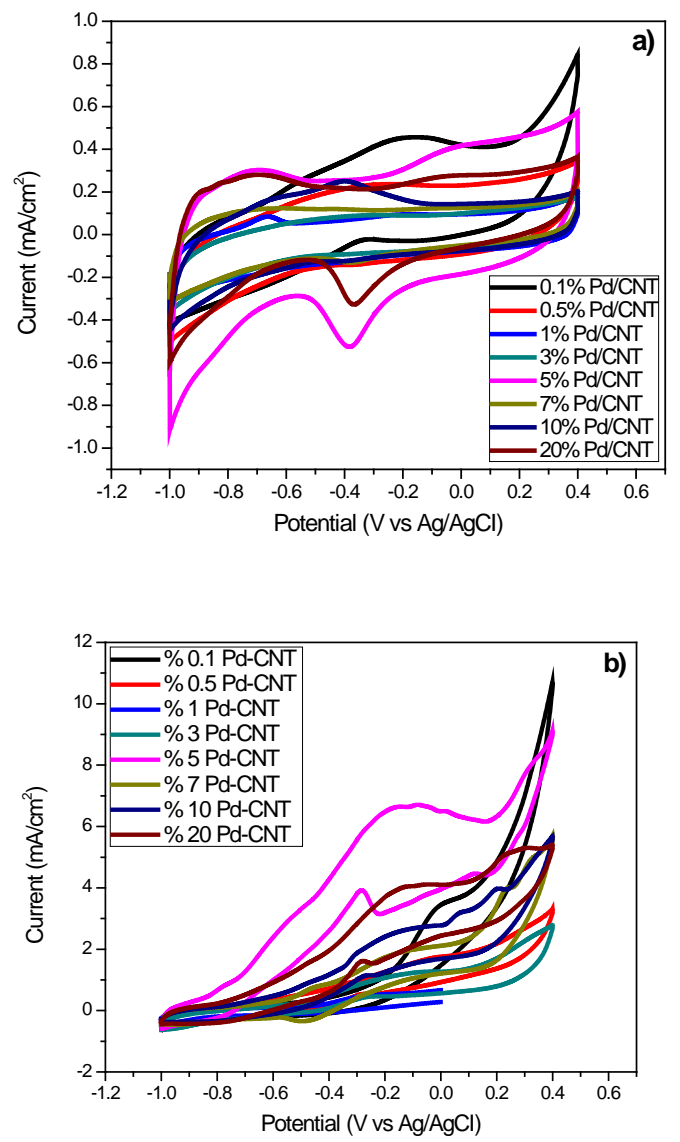

Figure 4. Cyclic voltammograms with a $50 \mathrm{mV} \mathrm{s}^{-1}$ scan rate in a) 1 $\mathrm{M} \mathrm{KOH}$ solution on Pd/CNT catalysts and b) $1 \mathrm{M} \mathrm{KOH}+0.5 \mathrm{M} \mathrm{N}_{2} \mathrm{H}_{4}$ solution on $\mathrm{Pd} / \mathrm{CNT}$ catalysts.

Table 3. Properties of the obtained peaks from CV results

\begin{tabular}{|c|c|c|c|c|c|c|}
\hline \multirow{2}{*}{$\begin{array}{c}\text { Catalysts } \\
0.1 \% \mathrm{Pd} / \mathrm{CNT}\end{array}$} & \multicolumn{2}{|c|}{$\begin{array}{c}\text { Forward Peak } \\
\left.\mathrm{I}_{\mathrm{f}}(\mathrm{mA} \mathrm{cm})^{-2}\right) \mathrm{E}(\mathrm{V})\end{array}$} & \multicolumn{2}{|c|}{$\begin{array}{l}\text { Reverse Peak } \\
\mathrm{I}_{\mathrm{r}}\left(\mathrm{mA} \mathrm{cm}^{-2}\right) \mathrm{E} \\
(\mathrm{V})\end{array}$} & \multirow{2}{*}{$\begin{array}{r}\mathrm{I}_{\mathrm{f}} / \mathrm{I}_{\mathrm{r}} \\
\\
---\end{array}$} & \multirow{2}{*}{$\begin{array}{c}\begin{array}{c}\text { Peak } \\
\text { Current } \\
\text { Density } \\
(\mathrm{mA} \\
\left.\mathrm{cm}^{-2}\right)\end{array} \\
3.57\end{array}$} \\
\hline & 3.86 & 0.020 & --- & --- & & \\
\hline $0.5 \% \mathrm{Pd} / \mathrm{CNT}$ & 2.31 & -0.004 & 1.12 & -0.26 & 2.06 & 1.76 \\
\hline $1 \% \mathrm{Pd} / \mathrm{CNT}$ & 0.77 & -0.203 & 0.24 & -0.70 & 3.20 & 0.54 \\
\hline $3 \% \mathrm{Pd} / \mathrm{CNT}$ & 1.74 & -0.015 & 1.10 & -0.21 & 1.58 & 1.23 \\
\hline $\begin{array}{c}\mathbf{5 \%} \mathbf{P d} / \mathbf{C N T} \\
\text { 7\% Pd/CNT }\end{array}$ & $\begin{array}{l}7.35 \\
2.36\end{array}$ & $\begin{array}{c}\mathbf{- 0 . 0 8 1} \\
-0.047\end{array}$ & $\begin{array}{l}4.40 \\
1.42\end{array}$ & $\begin{array}{l}-\mathbf{0 . 2 8} \\
-0.58\end{array}$ & $\begin{array}{l}\mathbf{1 . 6 7} \\
1.66\end{array}$ & $\begin{array}{l}\mathbf{6 . 8 1} \\
2.10\end{array}$ \\
\hline $10 \% \mathrm{Pd} / \mathrm{CNT}$ & 3.12 & -0.031 & 2.02 & -0.05 & 1.54 & 2.77 \\
\hline $20 \% \mathrm{Pd} / \mathrm{CNT}$ & 4.55 & -0.031 & 2.06 & -0.27 & 2.21 & 4.14 \\
\hline
\end{tabular}

EIS method is the best method to investigate in a large variety of catalyst properties [44]. Nyquist plots were obtained at different potentials for $5 \% \mathrm{Pd} / \mathrm{CNT}$ catalyst and at $0.4 \mathrm{~V}$ for different percent $\mathrm{Pd} / \mathrm{CNT}$ catalysts and presented in Figure 5. The Nyquist Plots obtained from EIS measurements were taken in $1 \mathrm{M} \mathrm{KOH}+0.5 \mathrm{M} \mathrm{N}_{2} \mathrm{H}_{4}$ solution. The Nyguist Plots are shaped usually as semicircle. These diameters of semicircles that correlate with charge transfer resistance $\left(\mathrm{R}_{\mathrm{ct}}\right)$ could inform about the electrocatalytic activity of catalysts [45]. The smaller the diameter of the semicircles, the charge transfer resistance of the catalyst is smaller, which specified the high electrocatalytic activity of the catalyst. Thus, more the hydrazine electrooxidation reaction gets faster. From the measurements taken at different potentials on 5\% Pd/CNT catalyst at $0.4 \mathrm{~V}$, we observed that this catalyst displayed the best catalytic activity in hydrazine electrooxidation reaction (Fig. 5a). Furthermore, in the measurements taken at $0.4 \mathrm{~V}$, it is found that among the $\mathrm{Pd} / \mathrm{CNT}$ catalysts, $5 \% \mathrm{Pd} / \mathrm{CNT}$ catalyst possess the best the charge transfer resistance in hydrazine electrooxidation reaction (Fig. 5b). This could be explained by the fact that Pd nanoparticles are well distributed on the CNT surface and leads to oxidation of more hydrazine molecules.
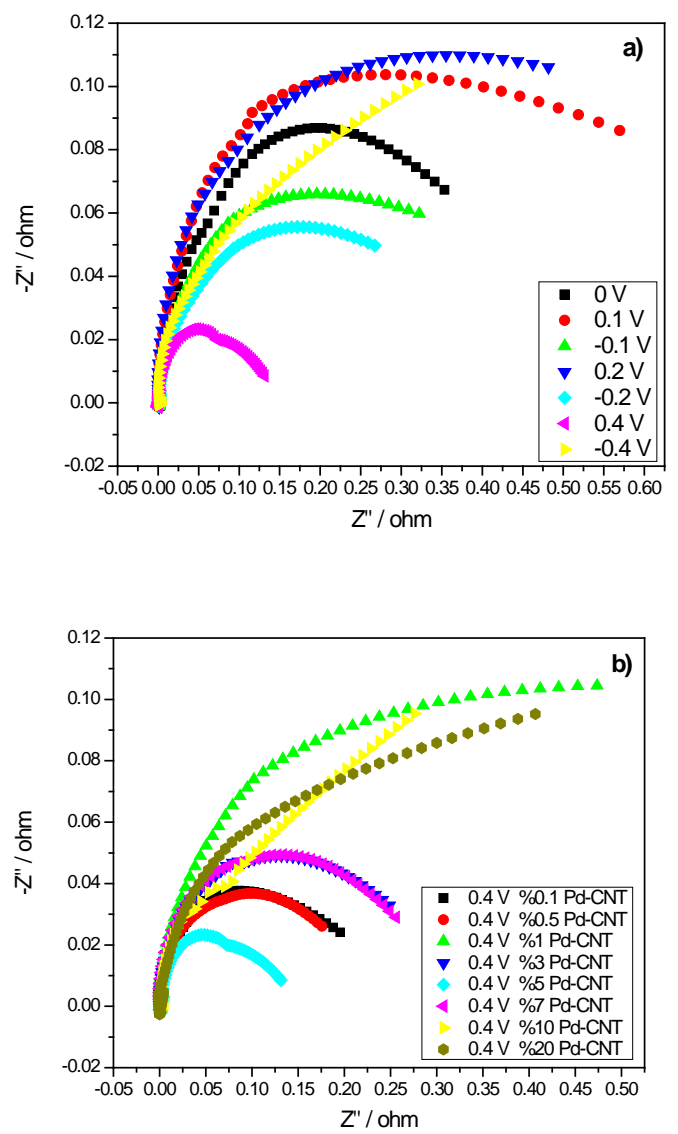

Figure 5. Nyquist Plots obtained in $1 \mathrm{M} \mathrm{KOH}+0.5 \mathrm{M} \mathrm{N}_{2} \mathrm{H}_{4}$ solution for electrodes modified with a) $5 \% \mathrm{Pd} / \mathrm{CNT}$ at different potentials and b) Pd/CNT catalysts at $0.4 \mathrm{~V}$. 


\section{Conclusion}

In this study, monometallic Pd/CNT supported catalysts were preapared via the $\mathrm{NaBH}_{4}$ reduction method. These monometallic catalysts were characterized with advance surface characterization techniques as $\mathrm{N}_{2}$ adsorptiondesorption, XRD, XPS, and TEM. To investigate their hydrazine electrooxidation activities, electrochemical techniques as $\mathrm{CV}$ and EIS were employed. Among the $\mathrm{Pd} / \mathrm{CNT}$ catalysts, 5\% Pd/CNT catalyst showed the best performance in hydrazine electrooxidation. As a result, hydrazine electrooxidation measurements and characterization conclusions of these catalysts led the following results and insights:

- $5 \% \mathrm{Pd} / \mathrm{CNT}$ catalyst exhibited V-type adsorptiondesorption shape with $\mathrm{H} 1$ type hysteresis loop, which is close to the mesoporous pore structure. This result indicates that 5\% Pd/CNT catalyst.has a large surface area.

- The average particle size of $5 \% \mathrm{Pd} / \mathrm{CNT}$ catalyst from XRD was determined as $6.94 \mathrm{~nm}$. In addition, the average particle size from TEM for 5\% Pd/CNT catalyst was obtained as $5.17 \mathrm{~nm}$. It shows that XRD and TEM average particle sizes are close.

- $5 \% \mathrm{Pd} / \mathrm{CNT}$ catalyst, according to CV and EIS results, displayed the highest hydrazine electrooxidation activity and long term stability compared to other Pd/CNT catalysts in hydrazine electrooxidation reaction.

- This study is unique in terms of evaluating the effect of hydrazine electrooxidation in an alkaline medium.

- Pd/CNT catalysts are promising as anode catalysts for direct hydrazine fuel cells

\section{Acknowledgment}

O. F. Er thank to the council of higher education (YOK) for 100/2000 scholarship and the Scientific and Technological Research Council of Turkey (TUBITAK) for 2211-A scholarship.

\section{References}

[1]. Er O.F., Caglar A., Ulas B., Kivrak H., Kivrak A., “Novel carbon nanotube supported Co@Ag@Pd formic acid electrooxidation catalysts prepared via sodium borohydride sequential reduction method", Materials Chemistry and Physics, 241, (2020), 122422.

[2]. Ellis M.W., Von Spakovsky M.R., Nelson D.J., "Fuel cell systems: efficient, flexible energy conversion for the 21st century”, Proceedings of the IEEE, 89, (2001), 1808-1818.
[3]. Armeanu D.Ş., Gherghina Ş.C., Pasmangiu G., "Exploring the causal nexus between energy consumption, environmental pollution and economic growth: Empirical evidence from central and Eastern Europe”, Energies, 12, (2019), 3704.

[4]. Ulas B., Caglar A., Sahin O., Kivrak H., "Composition dependent activity of PdAgNi alloy catalysts for formic acid electrooxidation", Journal of colloid and interface science, 532, (2018), 47-57.

[5]. Kivrak H., Atbas D., Alal O., Çögenli M.S., Bayrakceken A., Mert S.O., Sahin O., “A complementary study on novel PdAuCo catalysts: Synthesis, characterization, direct formic acid fuel cell application, and exergy analysis”, International Journal of Hydrogen Energy, 43, (2018), 21886-21898.

[6]. Sahin O., Duzenli D., Kivrak H., "An ethanol electrooxidation study on carbon-supported $\mathrm{Pt}-\mathrm{Ru}$ nanoparticles for direct ethanol fuel cells”, Energy Sources, Part A: Recovery, Utilization, and Environmental Effects, 38, (2016), 628-634.

[7]. Kivrak H.D., "The effect of temperature and concentration for methanol electrooxidation on Pt-Ru catalyst synthesized by microwave assisted route", Turkish Journal of Chemistry, 39, (2015), 563-575.

[8]. Huynh T.T.K., Tran T.Q.N., Yoon H.H., Kim W.-J., Kim I.T., “AgNi@ ZnO nanorods grown on graphene as an anodic catalyst for direct glucose fuel cells", Korean Journal of Chemical Engineering, 36, (2019), 1193-1200.

[9]. Ulas B., Caglar A., Kivrak A., Kivrak H., “Atomic molar ratio optimization of carbon nanotube supported PdAuCo catalysts for ethylene glycol and methanol electrooxidation in alkaline media”, Chemical Papers, 73, (2019), 425-434.

[10]. Wang Y., Wang Q., Wan L.-Y., Han Y., Hong Y., Huang L., Yang X., Wang Y., Zaghib K., Zhou Z., "KOH-doped polybenzimidazole membrane for direct hydrazine fuel cell”, Journal of Colloid and Interface Science, 563, (2020), 27-32.

[11]. Granot E., Filanovsky B., Presman I., Kuras I., Patolsky F., "Hydrazine/air direct-liquid fuel cell based on nanostructured copper anodes”, Journal of Power Sources, 204, (2012), 116-121.

[12]. Yamada K., Asazawa K., Yasuda K., Ioroi T., Tanaka H., Miyazaki Y., Kobayashi T., "Investigation of PEM 
type direct hydrazine fuel cell”, Journal of power sources, 115, (2003), 236-242.

[13]. Yi Q., Chu H., Tang M., Zhang Y., Liu X., Zhou Z., Nie H., "A novel membraneless direct hydrazine/air fuel cell”, Fuel cells, 14, (2014), 827-833.

[14]. Burshtein T.Y., Farber E.M., Ojha K., Eisenberg D., "Revealing structure-activity links in hydrazine oxidation: doping and nanostructure in carbide-carbon electrocatalysts”, Journal of Materials Chemistry A, 7, (2019), 23854-23861.

[15]. Yin W.X., Li Z.P., Zhu J.K., Qin H.Y., "Effects of $\mathrm{NaOH}$ addition on performance of the direct hydrazine fuel cell”, Journal of power sources, 182, (2008), 520523.

[16]. Crisafulli R., de Barros V.V.S., de Oliveira F.E.R., de Araújo Rocha T.,. Zignani S, Spadaro L., Palella A., Dias J.A., Linares J.J., "On the promotional effect of $\mathrm{Cu}$ on $\mathrm{Pt}$ for hydrazine electrooxidation in alkaline medium”, Applied Catalysis B: Environmental, 236, (2018), 36-44.

[17]. Wang W., Wang Y., Liu S., Yahia M., Dong Y., Lei Z., "Carbon-supported phosphatized CuNi nanoparticle catalysts for hydrazine electrooxidation”, International Journal of Hydrogen Energy, 44, (2019), 10637-10645.

[18]. Liang B., Wang Y., Liu X., Tan T., Zhang L., Wang W., Nickel-cobalt alloy doping phosphorus as advanced electrocatalyst for hydrazine oxidation, Journal of Alloys and Compounds, 807, (2019), 151648.

[19]. Wang T., Wang Q., Wang Y., Da Y., Zhou W., Shao Y., Li D., Zhan S., Yuan J., Wang H., “Atomically Dispersed Semimetallic Selenium on Porous Carbon Membrane as an Electrode for Hydrazine Fuel Cells", Angewandte Chemie, 131, (2019), 13600-13605.

[20]. Liu X., Li Y., Chen N., Deng D., Xing X., Wang Y., "Ni3S2@ Ni foam 3D electrode prepared via chemical corrosion by sodium sulfide and using in hydrazine electro-oxidation”, Electrochimica Acta, 213, (2016), 730-739.

[21]. Li C., Li M., Bo X., Yang L., Mtukula A.C., Guo L., "Facile synthesis of electrospinning Mn2O3-Fe2O3 loaded carbon fibers for electrocatalysis of hydrogen peroxide reduction and hydrazine oxidation", Electrochimica Acta, 211, (2016), 255-264.
[22]. Lao S.J., Qin H.Y., Ye L.Q., Liu B.H., Li Z.P., “A development of direct hydrazine/hydrogen peroxide fuel cell”, Journal of Power Sources, 195, (2010), 41354138.

[23]. Raoof J.B., Ojani R., Jamali F., Hosseini S.R., "Electrochemical detection of hydrazine using a copper oxide nanoparticle modified glassy carbon electrode”, Caspian Journal of Chemistry, 1, (2012), 73-85.

[24]. Lin X., Wen H., Zhang D.-X., Cao G.-X., Wang P., "Highly dispersed nickel nitride nanoparticles on nickel nanosheets as an active catalyst for hydrazine electrooxidation”, Journal of Materials Chemistry A, 8, (2020), 632-638.

[25]. Zabielaitė A., Balčiūnaitė A., Šimkūnaitė D., Lichušina S., Stalnionienè I., Šimkūnaitè-Stanynienè B., Naruškevičius L., Tamašauskaitè-Tamašiūnaitè L., Norkus E., Selskis A., "High Performance Direct N2H4-H2O2 Fuel Cell Using Fiber-Shaped Co Decorated with Pt Crystallites as Anode Electrocatalysts”, Journal of The Electrochemical Society, 167, (2020), 054502.

[26]. Wen H., Cao G.-X., Chen M.-H., Qiu Y.-P., Gan L.-Y., Wang P., "Surface phosphorization of hierarchically nanostructured nickel molybdenum oxide derived electrocatalyst for direct hydrazine fuel cell”, Applied Catalysis B: Environmental, 268, (2020), 118388.

[27]. Lei Y., Liu Y., Fan B., Mao L., Yu D., Huang Y., Guo F., "Facile fabrication of hierarchically porous $\mathrm{Ni}$ foam@ Ag-Ni catalyst for efficient hydrazine oxidation in alkaline medium”, Journal of the Taiwan Institute of Chemical Engineers, 105, (2019), 75-84.

[28]. Yang G.-W., Gao G.-Y., Wang C., Xu C.-L., Li H.-L., "Controllable deposition of Ag nanoparticles on carbon nanotubes as a catalyst for hydrazine oxidation”, Carbon, 46, (2008), 747-752.

[29]. Gao H., Wang Y., Xiao F., Ching C.B., Duan H., "Growth of copper nanocubes on graphene paper as free-standing electrodes for direct hydrazine fuel cells”, The Journal of Physical Chemistry C, 116, (2012), 7719-7725.

[30]. Asset T., Roy A., Sakamoto T., Padilla M., Matanovic I., Artyushkova K., Serov A., Maillard F., Chatenet M., Asazawa K., "Highly active and selective nickel molybdenum catalysts for direct hydrazine fuel cell”, Electrochimica Acta, 215, (2016), 420-426. 
[31]. Liu W., Xie J., Guo Y., Lou S., Gao L., Tang B., "Sulfurization-induced edge amorphization in coppernickel-cobalt layered double hydroxide nanosheets promoting hydrazine electro-oxidation”, Journal of Materials Chemistry A, 7, (2019), 24437-24444.

[32]. Chen L.-X., Jiang L.-Y., Wang A.-J., Chen Q.-Y., Feng J.-J., "Simple synthesis of bimetallic AuPd dendritic alloyed nanocrystals with enhanced electrocatalytic performance for hydrazine oxidation reaction", Electrochimica Acta, 190, (2016), 872-878.

[33]. Zhao A., Sun H., Chen L., Huang Y., Lu X., "Development of highly efficient and scalable freestanding electrodes for the fabrication of hydrazine-O2 fuel cell”, Materials Research Express, 6, (2019), 085533.

[34]. Akbar K., Kim J.H., Lee Z., Kim M., Yi Y., Chun S.H., "Superaerophobic graphene nano-hills for direct hydrazine fuel cells”, NPG Asia Materials, 9, (2017), e378-e378.

[35]. Yan X., Meng F., Xie Y., Liu J., Ding Y., “Direct N 2 H 4/H 2 O 2 fuel cells powered by nanoporous gold leaves”, Scientific reports, 2, (2012), 941.

[36]. Ding J., Kannan P., Wang P., Ji S., Wang H., Liu Q., Gai H., Liu F., Wang R., "Synthesis of nitrogen-doped $\mathrm{MnO} /$ carbon network as an advanced catalyst for direct hydrazine fuel cells”, Journal of Power Sources, 413, (2019), 209-215.

[37]. Sing K.S., Williams R.T., "Physisorption hysteresis loops and the characterization of nanoporous materials”, Adsorption Science \& Technology, 22, (2004), 773-782.

[38]. Kivrak H., Alal O., Atbas D., "Efficient and rapid microwave-assisted route to synthesize $\mathrm{Pt}-\mathrm{MnOx}$ hydrogen peroxide sensor”, Electrochimica acta, 176, (2015), 497-503.

[39]. Chen N., Deng D., Li Y., Liu X., Xing X., Xiao X., Wang Y., "TiO 2 nanoparticles functionalized by Pd nanoparticles for gas-sensing application with enhanced butane response performances”, Scientific reports, 7, (2017), 7692.

[40]. Lin J., Mei T., Lv M., Zhang C.A., Zhao Z., Wang X., "Size-controlled PdO/graphene oxides and their reduction products with high catalytic activity”, RSC Advances, 4, (2014), 29563-29570.

[41]. Wepasnick K.A., Smith B.A., Bitter J.L., Fairbrother D.H., "Chemical and structural characterization of carbon nanotube surfaces”, Analytical and bioanalytical chemistry, 396, (2010), 1003-1014.

[42]. Qi B., Di L., Xu W., Zhang X., “Dry plasma reduction to prepare a high performance $\mathrm{Pd} / \mathrm{C}$ catalyst at atmospheric pressure for CO oxidation”, Journal of Materials Chemistry A, 2, (2014), 11885-11890.

[43]. Caglar A., Kivrak H., "Highly active carbon nanotube supported PdAu alloy catalysts for ethanol electrooxidation in alkaline environment”, International Journal of Hydrogen Energy, 44, (2019), 11734-11743.

[44]. Eshghi A., "Graphene/Ni-Fe layered double hydroxide nano composites as advanced electrode materials for glucose electro oxidation”, International Journal of Hydrogen Energy, 42, (2017), 15064-15072.

[45]. Qu W., Wang Z., Sui X., Gu D., “An efficient antimony doped tin oxide and carbon nanotubes hybrid support of Pd catalyst for formic acid electrooxidation”, international journal of hydrogen energy, 39, (2014), 5678-5688. 